\title{
"Perceived idle wait and associated emotional discomfort: An analysis of retail waiting experience"
}

\begin{tabular}{|c|c|}
\hline AUTHORS & $\begin{array}{l}\text { Vinish P (D) } \\
\text { Prakash Pinto (D) } \\
\text { lqbal Thonse Hawaldar (D) } \\
\mathbb{R}\end{array}$ \\
\hline ARTICLE INFO & $\begin{array}{l}\text { Vinish P, Prakash Pinto and lqbal Thonse Hawaldar (2022). Perceived idle wait } \\
\text { and associated emotional discomfort: An analysis of retail waiting experience. } \\
\text { Innovative Marketing , 18(1), 1-11. doi:10.21511/im.18(1).2022.01 }\end{array}$ \\
\hline DOI & http://dx.doi.org/10.21511/im.18(1).2022.01 \\
\hline RELEASED ON & Thursday, 06 January 2022 \\
\hline RECEIVED ON & Saturday, 16 October 2021 \\
\hline ACCEPTED ON & Wednesday, 22 December 2021 \\
\hline LICENSE & $\begin{array}{l}(c) \text { EY } \\
\text { This work is licensed under a Creative Commons Attribution } 4.0 \text { International } \\
\text { License }\end{array}$ \\
\hline JOURNAL & "Innovative Marketing " \\
\hline ISSN PRINT & $1814-2427$ \\
\hline ISSN ONLINE & $1816-6326$ \\
\hline PUBLISHER & LLC "Consulting Publishing Company "Business Perspectives" \\
\hline FOUNDER & LLC "Consulting Publishing Company "Business Perspectives" \\
\hline
\end{tabular}

NUMBER OF REFERENCES

57

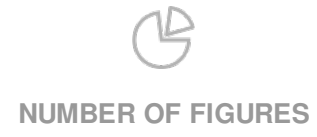

0
NUMBER OF TABLES

6

(C) The author(s) 2022. This publication is an open access article. 


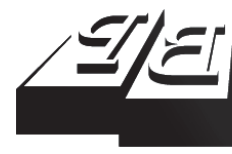

\section{BUSINESS PERSPECTIVES}

8

LLC "CPC "Business Perspectives"

Hryhorii Skovoroda lane, 10, Sumy, 40022, Ukraine

www.businessperspectives.org
Received on: $16^{\text {th }}$ of October, 2021 Accepted on: $22^{\text {nd }}$ of December, 2021 Published on: $6^{\text {th }}$ of January, 2022

(C) Vinish P, Prakash Pinto, Iqbal Thonse Hawaldar, 2022

Vinish P, Assistant Professor, Department of Business

Administration, St Joseph Engineering College, India.

Prakash Pinto, Professor, Department of Business Administration, St Joseph Engineering College, India.

Iqbal Thonse Hawaldar, Professor Department of Accounting \& Finance, College of Business Administration, Kingdom University, Bahrain (Corresponding author)

\title{
PERCEIVED IDLE WAIT AND ASSOCIATED EMOTIONAL DISCOMFORT: AN ANALYSIS OF RETAIL WAITING EXPERIENCE
}

\begin{abstract}
Waiting involves both cognition and emotions. It has a bearing on the overall perception of retail service quality. The advancement in retailing has triggered scholarly conversations on the psychological impact of waiting at the retail checkout. Prior studies confirm customers being deeply involved in the passage of time and time estimation during the entire waiting period. This study investigates the customer idle time and its implication on emotional discomfort resulting from crowding stress. The study employed confirmatory sampling wherein specific sample elements are chosen since they are the key respondents to confirm hypotheses being tested. Accordingly, 385 respondents (shoppers) visiting the leading organized retailers located in major localities in Bengaluru were approached. The responses were analyzed using a Chi-squared test and Pearson correlation. The outcome reveals that irrespective of age and gender, customers visiting the offline retail outlets experience emotional discomfort. The young customers aged 18-30 dislike waiting in the queue at the checkout compared to older customers. In contrast, gender did not affect the inclination to wait. The idleness during the checkout waits causes emotional discomfort on most occasions. The findings supplement the growing research in psychology on the actual and perceived consumption of time, focusing on idleness. The study concludes that customers desire to avert an unproductive use of time, thus lowering their emotional discomfort.
\end{abstract}

Keywords

JEL Classification

\section{INTRODUCTION}

Waiting is coupled with negative customer sentiments, undermining satisfaction levels (Tom \& Lucey, 1995). It adversely affects service appraisal (Haynes, 1990) and results in the relinquishment of service (Bielen \& Demoulin, 2007). Most organizations regulate the wait by marshaling customers in different queues (Rafaeli et al., 2002). Efforts are made to lessen the waiting time through operational techniques to acclimate the service facility to varying demands (Sarel \& Marmorstein, 1998). However, service providers fail to capitulate to the fluctuating demand despite the struggles due to capacity limitations (Pamies et al., 2016). The waiting line, even though a momentary social system, is discerned to confront all these intricacies.

Customers accrue stress when idle. The extent of strain can denote the degree of accrual of stress at any point in time. The critical negative outcome of waiting is 'time lost'. It is argued that the longer the perceived waiting time, the higher the negative evaluation of service (Hui \& Tse, 1996). Additionally, this is an essential process in the shopping activity (Gupta \& Sharma, 2014; Larson, 1987). Though earlier research findings confirm the positive distraction of consumers' per- 
ceived waiting by continuously providing the waiting information, the existing literature highlights the need for identifying the significance of other factors like uncertainty reduction and cognitive reappraisal of waiting time. Arguments are in favor of customers being deeply involved in the passage of time and time estimation during the entire waiting period (Zakay \& Hornik, 1991). The time in an idle state is perceived relatively longer compared to occupied time (Loehlin, 1959). The filled time is perceived to progress sooner than unoccupied time (Melbin et al., 1987).

Hornik (1984) contended that the customer wait duration is subjective and might not directly relate to the empirically measured wait times. The perceived wait time by the customer often diverges noticeably from the actual measured values, which infer the perceived duration of wait is on the higher side and is most likely to affect the consumer evaluation of their purchase and store experience (Seawright \& Sampson, 2007; Yan \& Lotz, 2006).

Operations management techniques have fairly addressed idle wait near the checkout: applying principles of queue disciplines, opening new counters when queue size exceeds the threshold, using emerging technologies such as mobile self-checkout, and exploring the feasibility of cashier-less stores. Digital disruption and innovative approaches, though, can relieve boredom and discomfort; the process involves considerable investments compounding surging operating costs, haunting Indian retailers. Perception management techniques, therefore, appear to be a viable, cost-effective alternative. Moreover, any impetuses that can divert a person's attention to the waiting period can significantly reduce a customer's negative service evaluation. The paper intends to draw the attention of retailers to the perceived idle wait of the customer waiting at the checkout and its implications on their emotional state. Thus, the paper will assist the retailers in minimizing the idle waiting time and keeping the customers satisfied.

\section{LITERATURE REVIEW AND HYPOTHESES}

The extent of intrusion is the critical element of 'crowding stress' and one of the many enablers of the personal intuition of being crowded (Schopler \& Stockdale, 1977). The term 'crowding' is broadly defined as interference created by the presence of others. Interference has sub-sets like perceived inadequacy of space, restrictions on behavioral choices, excessive stimulation from social sources and familiar or inappropriate contacts, unwanted social interactions, interference, and blocking or inability to attain desired levels of privacy (Schopler \& Stockdale, 1977, p. 82). Evans (1979) studied the consequence of crowding on human performance. Exposure to a stressful situation might cause a feeling of discomfort and even mental signs of stress. At times, the discomfort is associated with customer emotions and is termed as 'emotional discomfort' that may be understood as "notably feelings of being cramped and crowded and frustration at not being able to get away" (Bennett, 1998; Schmitt et al., 1992; Schopler \&
Stockdale, 1977). Boredom induced by waiting in line will lead to impatience, tension, and anxiety. Most supermarket customers are irritated, bored, frustrated, and unhappy to various extents while waiting at the checkout of a supermarket (Van Riel et al., 2012). The emotional response to wait tends to become more negative when the customer's perceived wait duration is high.

Demographic factors such as gender and age (Hemsley-Brown \& Oplatka, 2016), and psychological aspects such as perception (Kotler et al., 2005) are found to impact consumer behavior. Therefore, this study deliberates on age, gender, and perceived idle wait as important individual attributes persuading wait perception. Gender is often recognized as a critical predictor of contrasting outcomes in social psychology (Correll et al., 2007). Grewal et al. (2003) demoed convincing evidence to demonstrate the effect of gender on wait expectations and store evaluations. Cheng and Tsai (2014) observed a distinct tolerance level of waiting among passengers of different ages and gender. Experiments con- 
ducted by Kellaris and Mantel (1994) suggest that gender's interaction with mood can influence perceived time to be shorter or longer. Demographics such as age and gender can moderate queue perceptions and affective responses (Baker \& Cameron, 1996). In addition, varying age groups perceive the wait duration differently though gender did not show any impact on the latter (Wu et al., 2013). Thus, the study regard customers of specific age groups, gender to confront emotional discomfort. In the process of achieving a purchase goal, customers make progress of their experience, perception of the retail store, and attain satisfaction. Sherman et al. (1997) stated that a customer's emotional state might affect their shopping behavior. Customers evenly react to the length of the queue, context, and environment in which wait transpires (Schmitt et al., 1992). While Puccinelli et al. (2009) noted that a similar retail situation might generate very different results and moods, depending on the set goal. A packed retail store might be thrilling and motivating for a customer pursuing entertainment but produce a perception of inefficient service and disappointment for a customer who wishes to buy a specific set of goods to meet an urgent need. People's minds strolled irrespective of what they were performing, were less happy when their minds wandered than when not. In addition, their thoughts were mulling over better indicators of pleasure than what they were doing (Killingsworth \& Gilbert, 2010). Store preferences are indirectly influenced by customer density, gender, number of staff, and the number of fellow customers in the store through wait anticipations (Puccinelli et al., 2009). However, a direct relationship between customers' demographics and waiting tendency is barely explored in the literature.

Customers may have to wait before buying a product or service, during, and after the purchase is made (Taylor, 1994). Customers fill their wait times with physical and mental activities that divert their attention from the wait duration (Gilliland et al., 1946). Time fillers can be either context-related or unrelated based on their significance to the purchase situation (Taylor, 1994, 1995). Concerning customer-perceived wait duration, the cognitive timer model by Zakay (1989) posits 'individuals possess cognitive timers that use attentional resources to process temporal information', and assert that service setting can implicitly stimulate 'affect component' either through favorable social interaction or distraction, representing ways of filling time (Baker \& Cameron, 1996). Hornik (1984) buoyed this concept and emphasized that 'empty time' filled with no distraction will appear lengthier than a time occupied with something fascinating. Taylor (1995) acknowledged a similar trend when customers evaluated their service experience as higher even when there was a delay in the waiting. The filled time is perceived to progress sooner than unoccupied time (Melbin et al., 1987). Likewise, the time in an idle state is perceived relatively longer than occupied time (Loehlin, 1959). The idle wait was coined frequently in a hospital environment where patients eagerly wait to consult their doctor. Several studies on the idle and busy time perceptions shared the notion that waiting is a hatred experience and opined that people pursue varied experiences (Hsee et al., 2010, p. 926). Idle waiting time has conceivably received more attention in psychology (Buckner et al., 2008; Eastwood et al., 2012; Osuna, 1985; Yang \& Hsee, 2019). While most of the studies in operations research were on the idleness of the server and not the customer (Frenk et al., 1991; Haji \& Ross, 2015; Kanet \& Sridharan, 2000; Marshall, 1968; Powell \& Avi-Itzhak, 1967; Priyangika \& Cooray, 2016). Although the waiting line is generally witnessed in retail stores, the review failed to retrieve significant literature on idle waiting at the retail checkout. This might be on the grounds of certain studies refraining from using the keyword applied or because this element of waiting time has been recorded in queueing theory.

A great deal of research premeditated on alleviating the perceived wait times (Antonides et al., 2002). Anderson and Brodowsky (2001), Dellaert and Kahn (1999), and Gillam et al. (2014) recommended the implications of culture on waiting behavior. Pamies et al. (2016) pointed out that predominantly empirical studies on waiting were undertaken in merely three nations, i.e., the UK, the USA, and Canada. The knowledge of waiting behavior is thus limited 
to the above national perspectives only, which is culturally diverse. Cultural explications of time and waiting delays differ substantially and affect customers' behavior while encountering waits (Anderson \& Brodowsky, 2001; Graham, 1981). Pamies et al. (2016) expressed uncertainty over operationalizing standardized resolutions to waiting lines across cultural settings. The effect of perceived wait duration and idleness on emotional discomfort received marginal attention in the literature. In addition, the idea of contactless shopping has been gaining momentum in India in the recent past (Dash, 2020), when the world has already embraced the cashier-less store trend. Thus, the paper argues that idle wait still prevails in Indian retail checkouts, and this study is an effort towards identifying instances of idle wait and its association with customer demographics and emotional discomfort. Accordingly, the study proposes the following hypotheses:

$H_{1}: \quad$ Customer age is associated with the emotional discomfort in retail store checkout.

$\mathrm{H}_{2}: \quad$ Customer gender is associated with the emotional discomfort in retail store checkout.

$H_{3}: \quad$ Customer age is associated with the willingness to wait at the retail store checkout.

$\mathrm{H}_{4}$ : Customer gender is associated with the willingness to wait at the retail store checkout.

$H_{5}: \quad$ Customer perceived idle wait duration has an impact on the emotional discomfort.

\section{METHODS}

The study was conducted in a natural setting. Taylor (1994) and Van Riel et al. (2012) followed similar methods as they offer variance in queue length and causes in the stores concerned. In addition, Van Riel et al. (2012) suggested avoiding the carryover effects of prior shopping experiences by administering the questionnaire to respondents immediately after their store visit. Thus, the service perceptions and store evaluations were recorded instantly after shopping.
The research population consists of all resident and tourist customers visiting the organized retail chain outlets in Bengaluru Urban. The study has employed confirmatory sampling wherein specific sample elements are chosen since they are the key respondents to confirm the hypotheses. Accordingly, respondents (shoppers) visiting the ten leading supermarkets and hypermarkets located in major localities in Bengaluru were approached. Although the stores under consideration sell similar brands and log high sales turnover every day, they differ significantly in terms of store image, ambiance, the variety of merchandise, pricing, and promotion strategies. Table 1 provides the sample description and queuing behavior. The majority of the respondents $(41.6 \%)$ were from the age bracket of 31 to 40 years and least (8.1\%) from individuals above 50 years. Attempts were made to reach both genders (male and female) while collecting responses to obtain a broader depiction of the issue under study. Hence, there is no substantial variation in the share of opinion from both males (53.8\%) and females (46.2\%). Most of the respondents (48.6\%) prefer to visit on weekends (Saturday and Sunday), followed by respondents who do not have any preference of a day (20.5\%) for their shopping needs. Moreover, $47 \%$ of the respondents predominantly chose a line perceived as shorter. Whereas $22.3 \%$ of the respondents preferred a fast-moving queue, and $15.8 \%$ of the respondents joined the queue randomly without any inclination for service speed or line length.

\subsection{Scale development and validation}

Based on the suggestions of Tsang et al. (2017), a preliminary pilot testing of the questionnaire was conducted in Bengaluru for a small group of 50 respondents. The response scales were revised particularly on the waiting time as the sample respondents experienced a higher wait duration while shopping in the outlets concerned. The final version of the questionnaire is administered to a large representative sample of 385 respondents. Content validity of the constructs was ensured by consulting store managers and executives. The internal consistency of the questionnaire items under each construct is ensured using Cronbach's alpha. 
Table 1. Sample demographics and queuing behavior

\begin{tabular}{|c|c|c|}
\hline Characteristic & $\mathbf{n}$ & $\%$ \\
\hline \multicolumn{3}{|l|}{ Gender } \\
\hline Male & 207 & 53.8 \\
\hline Female & 178 & 46.2 \\
\hline \multicolumn{3}{|l|}{ Age } \\
\hline $18-30$ & 107 & 27.8 \\
\hline $31-40$ & 160 & 41.6 \\
\hline $41-50$ & 87 & 22.5 \\
\hline$>50$ & 31 & 8.1 \\
\hline \multicolumn{3}{|c|}{ Type of the outlet visited } \\
\hline Supermarket & 190 & 49.4 \\
\hline Hypermarket & 195 & 50.6 \\
\hline \multicolumn{3}{|l|}{ Day of visit } \\
\hline Weekend (Saturday and Sunday) & 187 & 48.6 \\
\hline $\begin{array}{l}\text { Weekday (Monday to Friday) except } \\
\text { Wednesdays }\end{array}$ & 72 & 18.7 \\
\hline On Wednesday & 32 & 8.3 \\
\hline During special/seasonal offers & 15 & 3.9 \\
\hline No preference/any day & 79 & 20.5 \\
\hline \multicolumn{3}{|c|}{ Choosing the queue to join } \\
\hline Randomly joined & 61 & 15.8 \\
\hline Joined the smaller queue & 181 & 47 \\
\hline Joined the fast-moving queue & 86 & 22.3 \\
\hline $\begin{array}{l}\text { Joined the queue based on the number of } \\
\text { items carried by other customers }\end{array}$ & 156 & 14.6 \\
\hline Other reasons & 1 & 0.3 \\
\hline
\end{tabular}

\section{RESULTS}

Customers visiting a retail outlet undergo varying levels of physical and mental activity while shopping. Discomfort could be experienced before joining the queue, while in the queue, during the billing, during the payment, and after the payment. The overall level of discomfort of all processes was measured by averaging the responses of respondents on five stages. Table 2 summarizes the analysis.
If the mean value is 1 to 2 , the respondent will have low discomfort, 2 to 3 as moderate discomfort, 3 to 4 as high discomfort, and 4 to 5 as very high discomfort. Analysis indicates the majority of the respondents experience moderate to high discomforts with a mean and standard deviation of 3.1 0.7 , signifying high discomfort. The variation in the mean level of discomfort is illustrated in Table 2. The rising and falling of the mean value denote a skewed bell-shaped curve. During the approach-depart course in a queueing system, a carryover effect of discomfort is observed where it gains momentum during the initial stage (before joining the queue) and steadily diminishes when the respondent makes contact with the target object (counter staff) during the billing.

The different levels of discomfort, such as mild, moderate, high, very high in a waiting area, are measured using the frequency distribution. Table 3 presents the analysis.

Table 3. Incidence of emotional discomfort

\begin{tabular}{|c|c|c|c|c|}
\hline $\begin{array}{c}\text { Level of } \\
\text { Discomfort }\end{array}$ & Frequency & Percentage & Mean & $\begin{array}{l}\text { Standard } \\
\text { deviation }\end{array}$ \\
\hline Mild & 34 & 8.8 & \multirow{5}{*}{3.1} & \multirow{5}{*}{0.7} \\
\hline Moderate & 164 & 42.6 & & \\
\hline High & 157 & 40.8 & & \\
\hline Very high & 30 & 7.8 & & \\
\hline Total & 385 & 100 & & \\
\hline
\end{tabular}

Table 3 indicates that the respondents visiting different outlets have experienced varying levels of discomfort. Most of the respondents experienced a moderate to a high level of discomfort with a percentage distribution of $42.6 \%$ and $40.8 \%$, respectively. Few respondents $(8.8 \%)$ on one extreme experienced a mild level of discomfort, whereas $7.8 \%$ of respondents experienced very high discomfort on the other extreme.

Table 2. Mean discomfort at different stages of waiting

\begin{tabular}{|c|c|c|c|c|c|c|c|c|}
\hline \multirow{2}{*}{ Situations } & Never & $\begin{array}{l}\text { Almost } \\
\text { never }\end{array}$ & $\begin{array}{c}\text { Occasionally/ } \\
\text { Sometimes }\end{array}$ & $\begin{array}{c}\text { Almost every } \\
\text { time }\end{array}$ & Every time & \multicolumn{3}{|c|}{ Result } \\
\hline & Count & Count & Count & Count & Count & Total & Mean & S. D \\
\hline Before joining the queue & 22 & 25 & 226 & 83 & 29 & 385 & 3.19 & 0.88 \\
\hline While in the queue & 11 & 15 & 143 & 167 & 49 & 385 & 3.59 & 0.86 \\
\hline During the billing & 20 & 42 & 180 & 111 & 32 & 385 & 3.24 & 0.94 \\
\hline During the payment & 40 & 93 & 169 & 58 & 25 & 385 & 2.83 & 1.02 \\
\hline After the payment & 53 & 118 & 157 & 30 & 27 & 385 & 2.64 & 1.04 \\
\hline Overall discomfort & & & & & & & 3.1 & 0.7 \\
\hline
\end{tabular}


Table 4. Association between demographic variables and emotional discomfort

\begin{tabular}{l|c|c:c:c}
\hline \multicolumn{1}{c|}{ Demographic variables } & Chi-square value & Degrees of freedom & $\mathbf{P}$ & Result \\
\hline Age & 5.895 & 3 & 0.117 & Not Significant \\
\hline Gender & 3.741 & 1 & 0.053 & Not Significant \\
\hline
\end{tabular}

Note: Significant at: ${ }^{*} 0.05, * * 0.01$ levels.

Table 5. Association between demographics and inclination to wait

\begin{tabular}{|c|c|c|c|c|}
\hline Particulars & Chi-square value & Degrees of freedom & p & Result \\
\hline Age & 23.044 & 3 & $0.000^{* *}$ & Highly significant \\
\hline Gender & 0.237 & 1 & 0.626 & Not significant \\
\hline
\end{tabular}

Note: Significant at: ${ }^{*} 0.05, * * 0.01$ levels.

The association of demographic variables with emotional discomfort is summarized in Table 4.

The age of respondents $(p=0.117)$ and gender $(p$ $=0.053)$, have a low impact on the emotional discomfort. However, they are not statistically significant, and hence, respondents' age and gender do not directly affect emotional discomfort. Thus, $H_{1}$ and $\mathrm{H}_{2}$ are rejected. It implies that irrespective of age and gender, customers experience emotional discomfort in the retail stores.

The study attempted to cognize the behavior of respondents when they noticed a lengthy queue at the checkout. As a result, respondents leave the queue in some instances. Also, other respondents may be trying to evade a queue since it is perceived as long, or they do not wish to stand for long in the queue. Table 5 presents the analysis of the association between customer demographics and waiting tendency.
The age of the respondents $(p=0.000)$ has a significant association with the tendency of waiting near the billing area. Thus, $H_{3}$ is accepted, inferring that customers of a specific age group are not willing to wait at the retail store checkout. In the current study, customers aged 18-30 years were hesitant to wait in the queue for a longer period. While gender $(p=0.626)$ has no association with a respondent's willingness to wait and hence $\mathrm{H}_{4}$ is rejected.

The discomfort experienced due to idle wait is measured for three checkout stages, i.e., before joining the queue, while in the queue, and during the billing. The analysis is presented in Table 6 .

Table 6 exhibits the correlation measure for the different days of outlet visit and discomfort due to the idle wait. The idle wait experienced by the respondents who visited on weekends is correlated positively with discomfort before joining the

Table 6. Correlation among idle wait durations and discomfort

\begin{tabular}{|c|c|c|c|c|c|}
\hline Day of visit & Statistical measure & $\begin{array}{l}\text { Discomfort before } \\
\text { joining the queue }\end{array}$ & $\begin{array}{l}\text { Discomfort while } \\
\text { in the queue }\end{array}$ & $\begin{array}{c}\text { Discomfort } \\
\text { during the billing }\end{array}$ & $\begin{array}{c}\text { Overall } \\
\text { Discomfort }\end{array}$ \\
\hline \multirow{3}{*}{$\begin{array}{l}\text { Weekend (Saturday and } \\
\text { Sunday) }\end{array}$} & Pearson Correlation & 0.105 & 0.187 & 0.166 & 0.211 \\
\hline & p & $0.039^{*}$ & $0.000^{* *}$ & $0.001 * *$ & $0.000 * *$ \\
\hline & $\mathrm{N}$ & 385 & 385 & 385 & 385 \\
\hline \multirow{3}{*}{$\begin{array}{l}\text { Weekdays (Monday } \\
\text { to Friday) except } \\
\text { Wednesdays }\end{array}$} & Pearson Correlation & 0.132 & 0.204 & 0.178 & 0.217 \\
\hline & p & $0.010 *$ & $0.000 * *$ & $0.000 * *$ & $0.000 * *$ \\
\hline & $\mathrm{N}$ & 385 & 385 & 385 & 385 \\
\hline \multirow{3}{*}{ On Wednesday } & Pearson Correlation & 0.09 & 0.168 & 0.217 & 0.191 \\
\hline & p & 0.079 & $0.001^{* *}$ & $0.000^{* *}$ & $0.000 * *$ \\
\hline & N & 385 & 385 & 385 & 385 \\
\hline \multirow{3}{*}{$\begin{array}{l}\text { During special/seasonal } \\
\text { offers }\end{array}$} & Pearson Correlation & 0.069 & 0.025 & 0.049 & 0.086 \\
\hline & $p$ & 0.174 & 0.627 & 0.335 & 0.094 \\
\hline & $\mathrm{N}$ & 385 & 385 & 385 & 385 \\
\hline
\end{tabular}

Note: Significant at: $* 0.05, * * 0.01$ levels. 
queue (where $r=0.105, p=0.039$ ), discomfort while in the queue (where $r=0.187, p=0$ ), and discomfort during the billing (where $r=0.166, p=$ 0.001 ), hence are significant. The idle wait experienced by the respondents who visited on weekdays except for Wednesdays are correlated positively with discomfort before joining the queue and is significant (where $r=0.132, \mathrm{p}=0.01$ ), discomfort while in the queue (where $r=0.204, p=0$ ), and discomfort during the billing (where $r=0.178$, $p$ $=0$ ), hence are significant. The idle wait is significantly positively correlated with discomfort while in the queue (where $r=0.168, p=0.001$ ), and discomfort during the billing (where $r=0.217, p=$ 0 ). The idle wait experienced by the respondents who visited on Wednesdays is correlated positively with discomfort before joining the queue (where $r$ $=0.09, p=0.079$ ). However, the relationship is statistically not significant. The idle wait experienced by the respondents who visited on Wednesdays is correlated positively with discomfort before joining the queue (where $r=0.069, p=0.174$ ), discomfort while in the queue (where $r=0.025, p=0.627$ ), and discomfort during the billing (where $r=0.049$, $p=0.335)$. Nevertheless, the relationship is statistically not significant across the stages of checkout. The idle wait duration is correlated positively with the overall discomfort for weekends (where $r=0.211, p=0$ ), weekdays (where $r=0.217, p=0$ ), and Wednesdays (where $r=0.191, p=0$ ), hence are significant. On special offer days, the correlation is positive but statistically insignificant (where $r=$ $0.086, p=0.094$ ). Hence, $H_{5}$ holds good for all days of a week except on seasonal or special offer days.

\section{DISCUSSION}

This study broadens the literature on idle wait in a retail checkout of India, the fifth-largest and preferred global retail destination. The research findings unfold the instances of idle wait and resultant emotional discomfort experienced by the customers visiting organized food and grocery outlets in Bengaluru, the IT capital of India. The younger customers in the 18 -30 age group (27.8\%) have less patience compared to customers aged more than 30 years. They expect a faster service or instant checkout, leaving several challenges for the store managers. Recruiting and building a skilled and motivated team, accommodating different check- out preferences in less tech-enabled stores accompanied by rising rentals, the exponential growth of e-commerce, and the recent pandemic are of utmost concern for the store owners.

Further, customers, irrespective of age, have undergone varying discomfort levels, with the obtained mean value indicating 'high discomfort' during their checkout process. The Chi-square test of independence asserts that both male and female customers are prone to experience emotional discomfort while waiting at the checkout. The Pearson correlation between day of visit to the outlet and emotional discomfort shows a significant relationship between the two on weekends $(r$ $=0.211, \rho=0.000)$, weekdays $(r=0.217, \rho=0.000)$, and Wednesdays $(r=0.191, \rho=0.000)$. Wednesdays are of specific importance to this study as the retail stores offer attractive discounts to boost midweek sales. As a result, stores expect to register higher store footfalls on special deals days and trigger crowding stress, a phenomenon examined in this study. However, the correlation was statistically insignificant in the case of other unique or festive/season days and overall emotional discomfort $(r=0.086, \rho=0.094)$. This could be due to the shortcomings in the survey where the responses of customers visiting the outlet during festive or special offer days were limited. Nevertheless, the idle wait of the customer can not be overlooked as it has instigated emotional discomfort on most occasions considered in this study.

\subsection{Implications of the study}

The retail waiting line has received significant attention for scholarly conversations. However, studies were limited on the Indian customers and their perception of waiting in a retail store. This study primarily contributes to the waiting line literature by investigating the instances of emotional discomfort of the customers waiting at the checkout counters. Results of the study indicate that customers undergo emotional discomfort of varying levels through different phases of the checkout process. The findings of the study directly align with Maister (1985). Moreover, the results on idle wait and emotional discomfort are broadly consistent with inferences drawn by Taylor (1994, 1995) and Van Riel et al. (2012). Demographics, wait perceptions, and idleness emerges to be the 
critical determinants of emotional discomfort. Although the current study is limited to hypermarkets and supermarkets in Bengaluru, the out- comes are relevant for retail outlets offering diverse merchandise and encountering situations involving waiting in the queue at the checkout.

\section{CONCLUSION}

Over time, extensive literature has developed on the idleness of the server at the checkout. In contrast, this study analyzed the idleness of customers in the queue. The present study shows that idle wait prevails in Indian retail checkouts and causes emotional discomfort to customers during checkout. Customers visiting the retail outlets consider idleness a dreadful waiting experience and relish a moderate level of busyness. Therefore, retail stores should pursue means of idleness aversion and meaningful busyness. The perceived wait duration could be reduced by increasing staffing, investing in technology, or managing wait perceptions. Additional counters could also be opened to manage the queue. However, the first two strategies involve considerable investment. Fluctuation in footfalls during peak and offpeak days, space restraints, increase in retail space demand, with associated cost curb the potential of opening additional counters. On the other hand, the perception management techniques require a proactive approach and not necessarily any investment, hence a practicable alternative.

\section{Limitations and scope for further research}

The study contemplates waiting issues experienced by customers shopping for food and grocery outlets during rush hours. Hence, customers visiting exclusive apparels and accessories stores were not approached for their viewpoint. Moreover, the current study measured the emotional discomfort experienced by the customers, and it does not examine the situational factors responsible for emotional discomfort at each checkout stage.

From a Brick-and-Mortar Stores' perspective, the current study broadens the understanding of emotional discomfort in a waiting line. Qualitative research is necessitated to understand the idle wait and stressing points of emotional discomfort and how customers perceive and cope with emotional discomfort. There has been limited research on waiting tendency and idle wait at the retail checkout. With the coronavirus pandemic, the notion of contactless shopping and payments has been gaining momentum. Startups and businesses are promoting innovative products that promise low or no contact for a safe experience. If the experience is fulfilling, will the retail automation lead to stranded employees? Finally, will it reduce the idle wait and emotional discomfort of the customers visiting the retail outlets? Additional inquiries will benefit in arriving at a more credible conclusion.

\section{AUTHOR CONTRIBUTIONS}

Conceptualization: Iqbal Thonse Hawaldar, Prakash Pinto.

Data curation: Vinish P.

Formal analysis: Iqbal Thonse Hawaldar, Vinish P.

Investigation: Prakash Pinto.

Methodology: Iqbal Thonse Hawaldar, Vinish P.

Project administration: Prakash Pinto.

Software: Vinish P.

Supervision: Prakash Pinto.

Validation: Iqbal Thonse Hawaldar, Vinish P, Prakash Pinto.

Visualization: Iqbal Thonse Hawaldar, Vinish P.

Writing - original draft: Iqbal Thonse Hawaldar, Vinish P, Prakash Pinto.

Writing - review \& editing: Iqbal Thonse Hawaldar, Prakash Pinto. 


\section{REFERENCES}

1. Anderson, B. B., \& Brodowsky, G. (2001). A cross-cultural study of waiting as a satisfaction driver in selected service encounters. Journal of East-West Business, 7(1), 11-36. https://doi.org/10.1300/ J097v07n01_02

2. Antonides, G., Verhoef, P., \& van Aalst, M. (2002). Consumer Perception and Evaluation of Waiting Time: A Field Experiment. Journal of Consumer Psychology, 12(3), 193-202. Retrieved from https://research.wur.nl/en/publications/consumer-perceptionand-evaluation-of-waiting-time-afield-experi

3. Baker, J., \& Cameron, M. (1996). The Effects of the Service Environment on Affect and Consumer Perception of Waiting Time: An Integrative Review and Research Propositions. Journal of the Academy of Marketing Science, 24(4), 338-349. https://doi. org/10.1177/0092070396244005

4. Bennett, R. (1998). Queues, customer characteristics and policies for managing waiting-lines in supermarkets. International Journal of Retail \& Distribution Management, 26(2), 78-87. https://doi. org/10.1108/09590559810206498

5. Bielen, F., \& Demoulin, N. (2007) Waiting time influence on the satisfaction-loyalty relationship in services. Managing Service Quality: An International Journal, 17(2), 174-193. https://doi. org/10.1108/09604520710735182

6. Buckner, R. L., Andrews-Hanna, J. R., \& Schacter, D. L. (2008). The brain's default network: Anatomy, function, and relevance to disease. Annals of the New York Academy of Sciences, 1124(1), 1-38. https://doi. org/10.1196/annals.1440.011

7. Cheng, Y. H., \& Tsai, Y. C. (2014). Train delay and perceived-wait time: passengers' perspective. Transport Reviews, 34(6), 710-729. https://doi.org/10.1080/01441647. 2014.975169

8. Correll, S. J., Thebaud, S., \& Benard, S. (2007). An
Introduction to the Social Psychology of Gender. In S. J. Correll (Ed.), Social Psychology of Gender (pp. 1-18). Emerald Group Publishing Limited. https://doi.org/10.1016/S08826145(07)24001-9

9. Dash, S. (2020, July 15). Scan and go stores crop up in India as contactless becomes key to shopping. Business Insider India. Retrieved from https://www.businessinsider. in/business/news/scan-and-gostores-crop-up-in-india-ascontactless-becomes-key-to-shopping/articleshow/76971890.cms

10. Dellaert, B. G. C., \& Kahn, B. E. (1999). How tolerable is delay?: Consumers' evaluations of internet websites after waiting. Journal of Interactive Marketing, 13(1), 41-54. https:// doi.org/10.1002/(SICI) 1520 6653(199924)13:1<41::AIDDIR4>3.0.CO;2-S

11. Eastwood, J. D., Frischen, A., Fenske, M. J., \& Smilek, D. (2012). The Unengaged Mind: Defining Boredom in Terms of Attention. Perspectives on Psychological Science, 7(5), 482-495. https://doi. org/10.1177/1745691612456044

12. Evans, G. W. (1979). Behavioral and Physiological Consequences of Crowding in Humans. Journal of Applied Social Psychology, 9(1), 27-46. https://doi. org/10.1111/j.1559-1816.1979. tb00793.x

13. Frenk, J. B. G., Thurik, A. R., \& Bout, C. A. (1991). Labour costs and queueing theory in retailing. European Journal of Operational Research, 55(2), 260-267. https://doi.org/10.1016/03772217(91)90230-S

14. Gillam, G., Simmons, K., Stevenson, D., \& Weiss, E. (2014). Line, line, everywhere a line: Cultural considerations for waiting-line managers. Business Horizons, 57(4), 533-539. https://doi.org/10.1016/j.bushor.2014.03.004

15. Gilliland, A. R., Hofeld, J., \& Eckstrand, G. (1946). Studies in
Time Perception. Psychological Bulletin, 43(2), 162-176. https:// doi.org/10.1037/h0062512

16. Graham, R. J. (1981). The Role of Perception of Time in Consumer Research. Journal of Consumer Research, 7(4), 335-342. https:// doi.org/10.1086/208823

17. Grewal, D., Baker, J., Levy, M., \& Voss, G. B. (2003). The effects of wait expectations and store atmosphere evaluations on patronage intentions in serviceintensive retail stores. Journal of Retailing, 79(4), 259-268. https://doi.org/10.1016/j.jretai.2003.09.006

18. Gupta, S., \& Sharma, D. (2014). Dimensions of Retail service convenience in emerging market settings - A qualitative investigation. Journal of Services Research, 14(1), 99-122. https:// search.proquest.com/docview/153 5387503 ? accountid $=85588$

19. Haji, B., \& Ross, S. M. (2015). A Queuing Loss model with Heterogeneous Skills based Servers under Idle Time ordering policies. Journal of Applied Probability, 52(1), 269-277. http:// doi.org/10.1239/jap/1429282621

20. Haynes, P. J. (1990). Hating to wait: Managing the final service encounter. Journal of Services Marketing, 4(4), 20-26. https://doi. org/10.1108/EUM0000000002522

21. Hemsley-Brown, J., \& Oplatka, I. (2016). Personal influences on consumer behaviour. In Higher Education Consumer Choice (pp. 44-64). Palgrave Pivot. https://doi. org/10.1007/978-1-137-49720-8

22. Hornik, J. (1984). Subjective vs. Objective Time Measures: A Note on the Perception of Time in Consumer Behavior. Journal of Consumer Research, 11(1), 615. https://search.proquest.com/docvi ew/215046404? accountid $=85588$

23. Hsee, C. K., Yang, A. X., \& Wang, L. (2010). Idleness aversion and the need for justifiable busyness. Psychological Science, 21(7), 926-930. https://doi. org/10.1177/0956797610374738 
24. Hui, M. K., \& Tse, D. K. (1996). What to Tell Consumers in Waits of Different Lengths: An Integrative Model of Service Evaluation. Journal of Marketing, 60(2), 81-90. https://doi. org/10.2307/1251932

25. Kanet, J. J., \& Sridharan, V. (2000) Scheduling with Inserted Idle Time : Problem Taxonomy and Literature Review. Operations Research, 48(1), 99-110. https://doi. org/10.1287/opre.48.1.99.12447

26. Kellaris, J., \& Mantel, S. (1994). The influence of mood and gender on consumers' time perceptions. In C. T. Allen \& D. R. John (Eds.), Advances in Consumer Research (pp. 514-518). Provo, UT: Association for Consumer Research. Retrieved from https:// www.acrwebsite.org/volumes/7647

27. Killingsworth, M. A., \& Gilbert, D. T. (2010). A Wandering Mind Is an Unhappy Mind. Science, 330(6006), 932. https://doi. org/10.1126/science.1192439

28. Kotler, P., Wong, V., Saunders, J., \& Armstrong, G. (2005). Principles of Marketing ( $4^{\text {th }}$ ed.). Pearson Education Limited.

29. Larson, R. C. (1987). Perspectives on Queues: Social Justice and the Psychology of Queueing. Operations Research, 35(6), 895 905. https://doi.org/10.1287/ opre.35.6.895

30. Loehlin, J. C. (1959). The influence of different activities on the apparent length of time. Psychological Monographs: General and Applied, 73(4), 1-27. https:// doi.org/10.1037/h0093741

31. Maister, D. H. (1985). The psychology of waiting lines. In J. Czepiel, M. A. Solomon, \& C. F. Surprenant (Eds.), The Service Encounter: Managing Employee/Customer Interaction in Service Businesses (pp. 113-123). Lexington Books. Retrieved from https://jnd.org/the_psychology_ of_waiting_lines/

32. Marshall, K. T. (1968). Some Relationships Between the Distributions of Waiting Time, Idle Time and Interoutput Time in the GI/ G/1 Queue. SIAM Journal on Applied Mathematics, 16(2), 324-327. Retrieved from https:// www.jstor.org/stable/2099295

33. Melbin, M., McGrath, J. E., \& Kelley, J. R. (1987). Time and Human Interaction: Toward a Social Psychology of Time. Contemporary Sociology, 16(6), 860-861. https://doi. org/10.2307/2071593

34. Osuna, E. E. (1985). The Psychological Cost of Waiting. Journal of Mathematical Psychology, 29(1), 82-105.

35. Pamies, M. d. M., Ryan, G., \& Valverde, M. (2016). Uncovering the silent language of waiting. Journal of Services Marketing, 30(4), 427436. https://doi.org/10.1108/JSM10-2014-0352

36. Powell, B. A., \& Avi-Itzhak, B. (1967). Queuing Systems with Enforced Idle Time. Operations Research, 15(6), 1145-1156. https://doi.org/10.1287/ opre.15.6.1145

37. Priyangika, J. S. K. C., \& Cooray, T. M. J. A. (2016). Analysis of the Sales Checkout Operation in Supermarket Using Queuing Theory. Universal Journal of Management, 4(7), 393-396. https://doi.org/10.13189/ ujm.2016.040703

38. Puccinelli, N. M., Goodstein, R. C., Grewal, D., Price, R., Raghubir, P., \& Stewart, D. (2009). Customer Experience Management in Retailing: Understanding the Buying Process. Journal of Retailing, 85(1), 15-30. https://doi. org/10.1016/j.jretai.2008.11.003

39. Rafaeli, A., Barron, G., \& Haber, K. (2002). The Effects of Queue Structure on Attitudes. Journal of Service Research, 5(2), 125-139. https://doi. org/10.1177/109467002237492

40. Sarel, D., \& Marmorstein, H. (1998). Managing the delayed service encounter: the role of employee action and customer prior experience. The Journal of Services Marketingarketing, 12(3), 195-208. https://doi. org/10.1108/02652329910300332

41. Schmitt, B. H., Dube, L., \& Leclerc, F. (1992). Intrusions Into Waiting
Lines: Does the Queue Constitute a Social System? Journal of Personality and Social Psychology, 63(5), 806-815. https://doi. org/10.1037/0022-3514.63.5.806

42. Schopler, J., \& Stockdale, J. E. (1977). An interference analysis of crowding. Environmental Psychology and Nonverbal Behavior, 1(2), 81-88. https://doi. org/10.1007/BF01145457

43. Seawright, K. K., \& Sampson, S. E. (2007). A video method for empirically studying wait-perception bias. Journal of Operations Management, 25(5), 1055-1066. https://doi. org/10.1016/j.jom.2006.10.006

44. Sherman, E., Mathur, A., \& Smith, R. B. (1997). Store environment and consumer purchase behavior: Mediating role of consumer emotions. Psychology and Marketing, 14(4), 361-378. Retrieved from https://search. proquest.com/docview/230395609 ?accountid $=193930$

45. Taylor, S. (1994). Waiting for Service: The Relationship between Delays and Evaluations of Service. Journal of Marketing, 58(2), 56-69. https://doi.org/10.2307/1252269

46. Taylor, S. (1995). The effects of filled waiting time and service provider control over the delay on evaluations of service. Journal of the Academy of Marketing Science, 23(1), 38-48. https://doi. org/10.1007/BF02894610

47. Tom, G., \& Lucey, S. (1995). Waiting time delays and customer satisfaction in supermarkets. Journal of Services Marketing, 9(5), 20-29. Retrieved from https:// www.deepdyve.com/lp/emeraldpublishing/waiting-time-delaysand-customer-satisfaction-insupermarkets-A0rZO8GPq4

48. Tsang, S., Royse, C. F., \& Terkawi, A. S. (2017). Guidelines for developing, translating, and validating a questionnaire in perioperative and pain medicine. Saudi J Anaesth, 11(Suppl 1), 8089. Retrieved from https://www. saudija.org/article.asp?issn $=1658$ $354 X$;year $=2017$; volume $=11$; issu $\mathrm{e}=5$; ppage $=80$; page $=89$; aulast $=$ Tsang 
49. Ullal, M. S., Hawaldar, I. T., Mendon, S., \& Joseph, N. (2020). The effect of artificial intelligence on the sales graph in Indian market. Entrepreneurship and Sustainability Issues, 7(4), 29402954. https://doi.org/10.9770/ jesi.2020.7.4(24)

50. Ullal, M. S., Spulbar, C., Hawaldar, I. T., Popescu, V., \& Birau, R. (2021). The impact of online reviews on e-commerce sales in India: A case study. Economic Research-Ekonomska Istraživanja, 34(1), 2408-2422. https://doi.org/1 0.1080/1331677X.2020.1865179

51. Van Riel, A. C. R., Semeijn, J., Ribbink, D., \& Bomert-Peters, Y. (2012). Waiting for service at the checkout: Negative emotional responses, store image and overall satisfaction. Journal of Service Management, 23(2), 144-169. https://doi. org/10.1108/09564231211226097
52. Vinish, P., Pinto, P., Hawaldar, I. T., \& Pinto, S. (2021). Impulse buying behaviour at the retail checkout: An investigation of select antecedents. Business: Theory and Practice, 22(1), 69-79. https://doi. org/10.3846/btp.2021.12711

53. Wu, J. R., Lu, S. G., \& Ge, Y. E. (2013). Identifying Factors Impacting Customers' Perceived Waiting Time in High Density Passenger Flow Waiting Areas. Procedia - Social and Behavioral Sciences, 96, 1801-1811. https://doi. org/10.1016/j.sbspro.2013.08.205

54. Yan, R.-N., \& Lotz, S. (2006). The Waiting Game: the Role of Predicted Value, Wait Disconfirmation, and Providers' Actions in Consumers' Service Evaluations. In C. Pechmann \& L. Price (Eds.), Advances in Consumer Research (pp. 412-418). Duluth, MN: Association for
Consumer Research. Retrieved from https://www.acrwebsite.org/ volumes/12466/volumes/v33/ NA-33

55. Yang, A. X., \& Hsee, C. K. (2019). Idleness versus busyness. Current Opinion in Psychology, 26, 15-18. https://doi.org/10.1016/j.copsyc.2018.04.015

56. Zakay, D. (1989). Subjective Time and Attentional Resource Allocation: An Integrated Model of Time Estimation. In I. Levin \& D. Zakay (Eds.), Time and human cognition: A life span perspective. (pp. 365-397). Amsterdam: Elsevier Science.

57. Zakay, D., \& Hornik, J. (1991). How Much Time Did You Wait in Line?: A Time Perception Perspective. Tel Aviv University. Retrieved from https://books.google.co.in/ books?id=iLqOYgEACAAJ 